\title{
Social report and environmental responsibility in brazil: a thematic review
}

\author{
Antonio Sergio Torres Penedo ${ }^{1}$ \\ Vinicius Silva Pereira ${ }^{2}$ \\ Marcelo Fodra ${ }^{3}$
}

\begin{abstract}
In the process of making public the green initiatives, companies have realized that social and environmental responsibility practices can be used to increase competitive advantage, minimize risk, manage reputation and transformed the social and environmental initiatives in corporate strategies. The concepts of environmental responsibility, economic and sustainable development and sustainability are very comprehensive. The main objective of this paper is to present the socio-environmental issues, sustainable development and sustainability and the relationship of the same with the social report. Initially aspects related to economic and sustainable development and their characteristics are presented. Then analyzes the evolution of the concept of social responsibility in Brazil, showing that it is often performed paternalistically disregarding the social and environmental impacts. The ways in which economic and financial sectors relate to the society, the description advances organizations in communicating their green initiatives, including the social report, are presented in this article.
\end{abstract}

Keywords: Social Responsibility, Sustainability, Social Report.

\section{Do crescimento econômico ao desenvolvimento sustentável}

\section{Resumo}

Os conceitos de responsabilidade socioambiental, desenvolvimento econômico, desenvolvimento sustentável e sustentabilidade são muito abrangentes. O principal objetivo desse artigo é apresentar os temas responsabilidade socioambiental, desenvolvimento sustentável e sustentabilidade. Os conceitos de desenvolvimento sustentável são apresentados juntamente com o desenvolvimento econômico devido à constatação que a manutenção do modelo de desenvolvimento atual é depreciativa, tanto em termos ambientais como em termos econômicos e socioambientais. O desenvolvimento sustentável, nesse sentido apresenta uma nova forma de se promover o desenvolvimento mundial, equilibrando as necessidades de resultados financeiros com a preservação do ecossistema terrestre e a melhoria da qualidade de vida das populações atuais e futuras. Embora na teoria do poluidor pagador, o desenvolvimento sustentável se apresente de forma viável, a sua execução é complexa, exigindo a coordenação e a colaboração de diversos agentes econômicos.

Palavras chave: sustentabilidade, desenvolvimento econômico, meio ambiente, responsabilidade socioambiental, desenvolvimento sustentável.

\footnotetext{
${ }^{1}$ Universidade Federal de Uberlândia - UFU. Faculdade de Gestão e Negócios - FAGEN. Email: penedo@ufu.br

${ }^{2}$ Universidade Federal de Uberlândia - UFU. Faculdade de Gestão e Negócios - FAGEN - Email: viniciuss56@ufu.br

${ }^{3}$ Universidade Federal de Uberlândia - UFU. Faculdade de Gestão e Negócios - FAGEN - Email: marcelo.fodra@ufu.br
} 
ReFAE - Revista da Faculdade de Administração e Economia

\section{INTRODUCTION}

Social responsibility has been a hotly debated topic and by society, not only by nongovernmental organizations and government entities, but also by private organizations. Since 1960, European workers and Americans began to demand of environmental information organizations, expanding the information provided the organizations, leading to the implementation of the Social Report in 1977. In France the publication of social report is mandatory in organizations They have 300 or more employees. The society has been demanding greater transparency about the disclosure of social, environmental and economic information, legitimizing the existence of organizations. As organizations consume environmental resources directly and indirectly, forming an integral part of society, they must disclose information to use these resources (TINOCO, 2006).

The Social Report is spreading in several European countries such as Germany, Italy, Netherlands, Portugal, Belgium, England, Spain, France and the United States. The Vietnam War was the catalyst of social movements that questioned the policies that had been adopted in the United States, as in organizations, especially with directly involved in the manufacture of weapons of war. With the spread of the outstanding challenges in some churches, foundations, veterans and public figures associations, they were the first social reporting, that would be the embryo of the Social Report instituted in France by law 77769 of July 12, 1977 (TINOCO, 2006).

The main objective of this paper is to present the socio-environmental issues, sustainable development and sustainability and the relationship of the same with the social report. Initially aspects related to economic and sustainable development and their characteristics are presented. Then analyzes the evolution of the concept of social responsibility in Brazil, showing that it is often performed paternalistically disregarding the social and environmental impacts. The ways in which economic and financial sectors relate to the society, the description advances organizations in communicating their green initiatives, including the social report, are presented in this article.

\section{METHODOLOGY}

Methodology is the study of methods and tools to conduct science, not limited to procedures and technologies used in the research. Search thorough elucidation, outlined, rigid and exact from all the action covered in the research work method, clarifying the type of research, the 
instrument used, the expected time and passed, the research staff, forms of tabulation and processing of data finally, what happened in the course of research.

The methodology used in this paper explains how we intend to analyze the evolution of the concept of economic growth for the current consensus for sustainable development. According to Miles and Huberman (1994) and Ghauri and Gronhaug (2005), qualitative research involves the researcher to obtain adequate knowledge of complex issues, such as human or organizational behavior. Godoy (1995), states that the qualitative research gets subsidies on places, interactive processes and people, through the interaction between the researcher and the situation. The qualitative approach to research is guided by a passage that allows the observation and appreciation of the searched situation. The procedure chosen for this research provides the weighting and capture the whole problem with a non-structured and exploratory methodology that allows to consider a problem and data considered conclusive.

For Marconi and Lakatos (2010) bibliographic research involves all published literature on affinity to the topic under study from books, theses, reports, spare publications, journals, newspapers etc. His intention is to allocate the researcher in direct contact with what has already been published in written form, spoken or filmed on any subject, including transcribed conferences or published or recorded. As Godoy (1995), the qualitative procedure accommodates a wide variety of work processes, judgment means and presentation of different effects and exhibitions. Regarding the research method, it is assumed that the content of this fact-finding work is an exploratory study, deployed with the design of mold is a universal view of the rough type, on a particular event, descriptive and explanatory, which, according to Gil (2007), aims to the knowledge of an exasperated problem, aiming to outline the properties of a predetermined event and the relationship between the variables involved.

This research can be defined as an exploratory study, motivated in the interest of adding knowledge on sustainable development and economic growth. Cooper and Schindler (2003), Hair et al. (2005) suggest that exploratory research is needed when inducing agents research, wish to provide an analysis of the limited information on the perceptions and behaviors to gain knowledge about the nature of a particular problem.

\section{LITERATURE REVIEW}

According to Pereira (2007), in Brazil can be seen three periods of social responsibility. Initially, without interference from the state, the blessings offered by organizations to their officials were seen as "favor" personal. During this period, marked by the beginning of industrialization and accelerated urbanization, there was no effective regional integration. Due 
to the industrialization phase and a lack of available labor in the cities, industrial if you have to build workers' villages in order to meet its need for workers. These workers' villages, seen as favors the employers to their employees had public and church support due to the association of construction to improve the hygienic conditions and the way they inserted a discipline of the poor through work to produce the desired working class.

On the one hand, the villages imposed tight control to employees, but otherwise minimized shortcomings with decent facilities for its internal members. Thus, the bosses highlighted the improvements not an imperative for production, but as a result of the awareness of the entrepreneur to society's needs. In that first moment of Corporate Social Responsibility, all blessings are regarded as charity offered voluntarily by employers (PEREIRA, 2007).

For Rago (1989), the workers 'villages were employers' tactics to keep workers around the productive unit during the period of creation of the Brazilian free labor market. Thus with these workers' villages the bosses could control the workers' routine by establishing the reproduction of the factory's lifestyle in the daily life of the employees, making the lives of the workers a mere representation of the factories by imposing on these workers' villages the lifestyle of the factories. With the determination in the workers' villages of the reflection of the factories, a set of codes of conducts with punitive and disciplinary norms pursuing the worker during all his time is established. Thus, eliminating the moments that separate life and work, the workers 'villages discipline the daily relations of the workers, establishing a place of control, control and planning of workers' lives

In a second period, with a change of rationality imposed by urban growth and the expansion of capitalism in Brazil, labor laws are created that determine minimum conditions that the entrepreneur should meet. The parent image of the boss begins to be replaced by impersonal scientific discipline with the inclusion of the technical-scientific community in the Brazilian space. In 1942, the businessmen with the President Getúlio Vargas, created the National Service of Industrial Learning - SENAI in order to train workers for industries as scientific methods that led to a large increase in productivity. Weinstein (2000), the structure of SENAI, created with State regulations, eliminating trade union involvement in the training process, enabling industrial credit for initiative which served in the opinion of society, the interests of the workers and the nation. But at SENAI in addition to technical training, was produced the ideal worker as scientific rationality with notions of behavior required in industries, demonstrating a real interest in train alienated labor to be used in industries where repetitive work. 
In 1946 to expand the services provided by SENAI addition to the training of industrial workers, they are created the Social Service for Industry - SESI, National Service of Trade Learning - SENAC and the Social Service of Commerce - SESC. The SENAC would exercise similar to SENAI, but focused on training workers for trade. The SESC and SESI dedicated themselves to basic assistance activities for the population and the inclusion of desired values with the family of industrial workers and trade respectively (PEREIRA, 2007). An increase in the production building on a better organization of the production process, bringing together interests of businessmen, state officials and was the flag that period.

The third period starts from disruptions that occurred with the previous logic and especially the strengthening of the discourse on the decline or even the end of state interference in social issues argued by the need for global competition and continuous decrease of the organizations costs. During this period, there is a retraction of the social actions of the state regulation and the multiplication of business institutes maintained by organizations interested in improving your image through certifications, awards and standards as the social report with the use of communication as part of marketing social. Many organizations have realized that by associating their image to a socially responsible organization, they add value to their products, besides increasing its market value and win customers interested in social and environmental responsibility. In the following table, there is a summary of the characteristics of each period of social action organizations in Brazil.

\section{Table 01: The periodization of social actions in Brazil}

\begin{tabular}{|c|c|c|}
\hline Until 1930 & Between 1930 and 198 & From 1980 \\
\hline $\begin{array}{l}\text { - Social action focused on } \\
\text { the realization of the } \\
\text { entrepreneur with great } \\
\text { religious motivation; } \\
\text { - Absence of } \\
\text { regulation; } \\
\text { - Organizations } \\
\text { territorial limitation. }\end{array}$ & $\begin{array}{l}\text { - Construction } \\
\text { villages, kindergartens } \\
\text { and hospitals for the } \\
\text { workers. } \\
\text { - Emergence of pressure } \\
\text { from unions; } \\
\text { - Top of state regulation; } \\
\text { - Church Guidance for } \\
\text { Social Action of } \\
\text { entrepreneurs; } \\
\text { - Establishment of social } \\
\text { service institutions of } \\
\text { industry and commerce } \\
\text { (SENAI, SESI, SESC, } \\
\text { SENAC). }\end{array}$ & $\begin{array}{l}\text { - Retraction of state } \\
\text { regulation of social actions; } \\
\text { - Extension of corporate } \\
\text { institutions such as institutes } \\
\text { and foundations; } \\
\text { - Start of certifications, } \\
\text { awards and standards as well } \\
\text { as the social report; } \\
\text { - Use of a language as part } \\
\text { of the social marketing } \\
\text { (social responsibility, } \\
\text { citizenship, sustainability). }\end{array}$ \\
\hline
\end{tabular}

Source: Pereira (2007) 
Corporate social responsibility emphasizes the impact of company activities with the social actors directly or indirectly impacted. His concept has been deepened by various institutes and organizations as a tool in achieving social and environmental responsibility of organizations such as the ETHOS Institute, the IBASE (Brazilian Institute of Social and Economic Analyses), the Institute of Corporate Citizenship. All these entities represent the common interest of social issues in the country.

To promote transparency of social and environmental responsibility of organizations, created the Social Report, which can be set, according to Iudícibus and Marion (2001) as such as reports that contain elements that make it possible to identify the social performance aspect of the organization during a given period, the characteristics of the internal members and their responsibility in the financial statements and their mutual influence with society and others involved.

The publication of the Social Report is not mandatory in Brazil, but it is a report that provides environmental information, information about the internal policy focusing on: quality of life of insiders, the company's stance on the environment, the relevance contributions to the community, among others.

This raises a new conception of accounting science, focused on the social and environmental impacts. The Social Report sets out to highlight the actions of organizations in constant pursuit of utility maximization in terms of social responsibility.

The Social Report may be published by organizations, bringing together a range of information on social and environmental activities for its internal members and the community showing the resources applied to employees and the public that gets its direct influence. The Social Report is a tool established by various organizations with the ability to specify and adjust the company's concern with people and life on the Earth's ecosystem.

In its expanded conception, the Social Report provides the organization of interaction with the elements around them and contribute to their existence, as the local community, human and natural resources.

Briefly, the Social Report is a description of the key environmental performance indicators of the company in order to demonstrate the environmental activities of organizations. It is considered a mechanism that expands the dialogue with all stakeholders the company relates to: shareholders, NGOs, consumers, local communities, suppliers, internal members, government, financial market and society.

Sá (1999) affirms that the sustainability report demonstrates the acts of the organization shaped for the society in the most diverse classes. Tinoco (2006) defines Social Balance as a 
form of management that aims to report socio-environmental information on the performance of the organization to the most different entities of society. This view is shared by other authors such as Mendes et. Al. (1998) because they believe that BS is a mechanism, management and information mechanism, which fully demonstrates the economic and socioenvironmental information of the performance of the entities, providing a vision of the socioenvironmental participation of the organization in its operating environment.

For Tinoco (2006) the Social Balance is an important warning explaining the socioenvironmental situation besides the organization's financial situation.According to Costa, Visconti and Azevedo (2002), Social Report is the publication of social and environmental values invested by organizations in fulfilling its social function among its employees and stakeholders. In this sense, they consider it a program of activities of the organizations, which aims to promote transparency to the information that matters not only to the shareholders of the companies, but to a greater number of stakeholders such as employees, suppliers, investors, partners, consumers and community.

Araújo (2001) points out that the dimensions of the social responsibility of an organization are reported in the social report. Thus, the social and environmental responsibilities can be measured through this statement. This author believes that the social report shows the organization's commitment to present and future generations.

Tinoco (2006) mentions that an organization is the reflection of its workers. Performing a social statement is the way to describe employees, their progress, their classes, the conditions that carry on their activities, how to progress, that is, how employees are respected in relation to other social actors. Costa, Visconti and Azevedo (2002) believe that social report models have slight distortions, but it has in common internal and external aspects of the company.

Duarte and Dias (1985) warn that the lack of proposed standards in the Social Report explains why the assessment of the organization's performance in the environmental area is presented in various ways differing from the traditional financial and economic report delivered at the end of the year.

A Social Report model interpreted as ideal would be based on the costs of notions and social benefits. Thus, the social report should reflect all the damages that business activities have on society and not only the costs traditionally borne, and incorporate all the benefits to society. The difficulty of assigning a financial value to some items is the greatest obstacle in the creation of this assessment. More than difficulty, there is opposition to the measurement of the damage and the recognition of them. 
A commonality between the different types of Social Report is the emphasis on the following: profit organization, the organization's revenues, the organization payroll, number of internal members, taxes, fees, taxes and social charges, feeding the internal members, training and professional qualification, health of internal members, given socio-economic benefits, environmental investments, donations to the local community etc.

The Brazilian Institute of Social and Economic Analyses (IBASE) developed a model involving multiple items a social report must present and will be shown in the next section. One of the most widespread in the country and features the following information: deleted gross revenue from taxes and contributions, rebates, returns, trade discounts; total payroll; restaurant, meal ticket and other expenses with the power of internal members; retirement plans, social security contributions, supplement benefits to retirees and their dependents; health plan, health care, preventive medicine programs, health spending, including retirees; training, internship programs, scholarships for the internal members and their dependents, magazine subscriptions, library, investments in education and training internal members; nursery for children of internal members; recreational activities, houses offered to internal members; taxes, levies, fees, taxes and municipal, state and federal payroll taxes; investments in the local community, pollution, investment in non-polluting methods, investments aimed at environmental quality; conservation of environmental resources, social and educational campaigns; and other information that the organization considers important for its social and environmental initiatives.

The Social Report is a demonstration to the whole community. Information should be those of interest to social ones. Sa (1999) referring to the social report says it shows everything that the organization has contributed or added to society, that is, what remunerated to internal members, the government, financial institutions, the educational and environmental care, compensation the partners, how much he bought in the country and abroad etc.

For Godoy et. al. (2007), the Social Report can be regarded as a method of assessment, which market analysts, investors and funding agencies (BNDES, IDB etc.) add to the list of forms and documents to understand and evaluate the risks and projections from the company. Initially, the Social Report should show the message of the president of the company, defining the organization's commitments and summarize the document. Later the enterprise profile, demonstrating the kind of product and services of the company, its brand, the amount of internal members, the last published financial statements etc. Then approach to information about the organization as a mission, evolution, principles and strategic vision of the organization. Then the activity detailing how the organization deals with the social actors and 
the economic and environmental performance indicators is reported. It also presents additional data from the ethical and the organization's future vision. Subsequently, sets of economic and environmental performance indicators are shown. In the section of financial indicators is information of the organization's economic impact on society and distribution of the generated values. In the section of social indicators, information is presented on the internal members of the organization, labor rights and human rights. Finally, we present the annexes, which are the information contained in the reports would divert the focus of the reader, and therefore deserve special attention.

Internationally organizations use monitoring mechanisms and accountability, promoting their social and environmental practices developed through audits, certifications, procedures and social reports. These are accounting standards developed by organizations, showing a set of standards and indicators that can be earned relating to labor, social and environmental conduct adopted. As well as the ISO 9000 and ISO 14000 procedures certifying organizations for their managerial capacity and the environmental respect, the standards social report 8800 and SA 8000 , developed by the British, have the same effect as the ISO, but are aimed at environmental area. Note that these certifications only attest compliance with labor legislation, which would be unnecessary because non-compliance should result in punishment, and as this does not happen compliance is awarded.

According to Melo Neto; Froes (2001) certification is given to organizations and their trading partners that respect the labor laws and endow their employees with the rights predicted in the legislation. The regulation and methodology BS 8.800 is designed to guarantee the essential conditions of safety and health for the workers. The regulation and methodology SA 8.000 is more specific, dealing with the abuse of child labor in the sphere of the operational units of the organizations and their partners.

The AA1000 standard was developed by the Institute of Social and Ethical Responsibility (Accoutability Institute) in England in order to ensure the quality of social responsibility. It is a standard and procedure that can be used to confirm the quality of social responsibility, manage and communicate social responsibility (Levy, 2004).

AA1000 proposes the dialogue between all stakeholders in the business activities of enterprises and comprises a set of procedures and standards underpinned by the principle of social and environmental responsibility for all social actors involved, supporting organizational learning contribute to sustainable environmental development (LEVY, 2004). The Social Report meets all social actors that interact with the disclosing organization of social report as administrators providing vital data and information for decision-making; 
suppliers and investors stating how the organization relates to the internal members and the environment; offering consumers an idea about the quality of offered goods and services and the state helping him to formulate public policy. Thus, the social reports come to be the main resources used in the dissemination of responsible social and environmental practices.

\section{FINAL CONSIDERATIONS}

This article discusses the issues of economic development, environmental responsibility, philanthropy, citizenship and business ethics for a better understanding of the subject. The concepts of sustainable development were studied along with economic development because of the realization that maintaining the current development model is derogatory, both environmentally and in economic and environmental terms. Sustainable development in this sense presents a new way to promote world development, balancing the needs of financial results to preserving the Earth's ecosystem and improving the quality of life of current and future populations. Although in theory the polluter pays, sustainable development is presented viably, its implementation is complex, requiring coordination and cooperation of various social actors. They were also presented some awards and certifications related to corporate responsibility and ethics. Currently organizations began using mechanisms for monitoring and accountability instituting disclosure and transparency to the developed social and environmental practices, highlighting the audits, certifications and social reports. This communication to society aims to highlight data on the management of social and environmental conditions, opposite the collection of the company has been making organizations in order to be socially and environmentally responsible. Thus, for future academic work is suggested to study the initiatives for assessing social and environmental responsibility and mechanisms and to support sustainable development tools.

\section{BIBLIOGRAPHIC REFERENCES}

ARAÚJO, F. J. Dimensões da Responsabilidade Social da empresa. Revista Brasileira de Contabilidade. $\mathrm{n}^{\text {o }}$ 129, Maio/Junho de 2001.

COOPER, D. R., SCHINDLER, O. S. Métodos de pesquisa em administração. 7. ed. Bookman, 2003.

COSTA, C.; VISCONTI, G. R. e AZEVEDO, C. B. Balanço Social e outros aspectos da Responsabilidade Social Corporativa. [on-line] http://www.bndes.gov.br, 2002.

DUARTE, G.; DIAS, J. M. Responsabilidade Social: a empresa hoje. São Paulo: LTC, 1985.

ReFAE - Revista da Faculdade de Administração e Economia, v. 8, n. 2, p. 209-219, 2017 
GHAURI, P. N., \& GRØNHAUG, K. Research methods in business studies: A practical guide. Pearson Education, 2005.

GIL, A. C. Como elaborar projetos de pesquisa. 4. ed. São Paulo. Atlas, 2007.

GODOY, A. S. Introdução à pesquisa qualitativa e suas possibilidades. Revista de Administração de Empresas - RAE. São Paulo, v. 35, n. 2: 57-63, 1995.

GODOY, M. et. al. Balanço Social: Convergências e Divergências entre os Modelos do IBASE, GRI E Instituto ETHOS. In: I Congresso UFSC de Controladoria e Finanças, Anais..., Florianópolis, 2007.

HAIR, J. et. al. Fundamentos de Métodos de Pesquisa em Administração. Porto Alegre. Bookman, 2005.

IUDÍCIBUS, S.; MARION, J. C. Dicionário de Termos de Contabilidade. São Paulo: Atlas, 2001.

LEVY, D. Incorporando os conceitos de marketing social e responsabilidade social na atuação empresarial: um estudo de caso. São Paulo, 2004. 30 p. Disponível em: $<$ http://www.valoronline.com.br>. Acesso em: 23 jan. 2009.

MARCONI, M. A, LAKATOS, E. M. Técnicas de pesquisa: Métodos. São Paulo: Atlas, 2010.

MELO NETO, F.; FROES, C. Gestão da Responsabilidade Social Corporativa: o caso brasileiro. Rio de Janeiro: Qualitymark Ed., 2001.

MENDES, A. E. et. al. Balanço Social: Exercício de Cidadania. Revista de Contabilidade do CRC-SP. Ano II, n. ${ }^{\circ}$ 6, Novembro de 1998.

Miles, M. B., \& Huberman, A. M. Qualitative data analysis: An expanded sourcebook.

Sage. 1994.

PEREIRA, E. A. A. A empresa e o lugar na globalização: a responsabilidade social empresarial no território brasileiro. 2007. 205. Dissertação (Mestrado em Geografia Humana) - Faculdade de Filosofia, Letras e Ciências Humanas, Universidade de São Paulo, São Paulo, 2007.

RAGO, M. Do cabaré ao lar: uma utopia da cidade disciplinar - Brasil, 1890-1930. Rio de Janeiro: Paz e Terra, 1989.

SÁ, A. L. Teoria da Contabilidade. $2^{a}$ ed. São Paulo: Atlas, 1999.

TINOCO, J. E. P. Balanço Social. São Paulo: Atlas, 2006.

WEINSTEIN, B. (Re)formação da classe trabalhadora no Brasil (1920 - 1964). São Paulo: Cortes. Universidade São Francisco, 2000. 